\title{
Criteria for the Evaluation of Public Relations Effectiveness
}

\section{Lina Kazokiene, Jurgita Stravinskiene}

\author{
Kaunas University of Technology Panevezys Institute \\ Nemuno str. 33, LT-37164, Panevezys, Lithuania \\ e-mail:lina.kazokiene@ktu.lt
}

\author{
Kaunas University of Technology \\ Laisves ave. 55, LT-44309, Kaunas, Lithuania \\ e-mail:jurgita.stravinskiene@ktu.lt
}

crossref http://dx.doi.org/10.5755/j01.ee.22.1.222

The article reveals the specifics of public relations '(PR) effectiveness evaluation while emphasizing its complex nature. Elements of PR effectiveness evaluation complex and their expediency are analyzed. After identifying the lack of clear corpus of the criteria for PR effectiveness evaluation, a research was carried out on the PR effectiveness evaluation in Lithuanian business companies. Quantitative and qualitative researches expanded the cognizance of PR effectiveness evaluation and made it more accurate. Based on the results of the researches, clear and adaptable corpus of evaluation criteria was suggested that ensures the adequacy of projected PR effectiveness evaluation solutions to the situation in question. Through the study of direct experience, the list of criteria for all stages of PR effectiveness evaluation was expanded and an additional stage of interim evaluation was identified. Evaluation criteria were grouped in line with the consistency of $P R$ effectiveness evaluation process, defined by input, implementation, interim evaluation and impact evaluation stages. Results of the researches are presented following the same order of sequence. Criteria for the evaluation of PR objectives are suggested based on hierarchical levels of objectives, while distinguishing between evaluation criteria for tasks, target audiences and action plan. In PR implementation stage, the following criteria are presented: simplicity, informativeness, veracity, ethicality and novelty of communication message, purpose-centrality of information provided, attractiveness of the media and attractiveness of message presentation. When discussing the PR impact, criteria for the evaluation of different PR results - outputs, outtakes and outcomes - are presented. Moreover, the importance of relationship quality criterion was emphasized, allowing envisaging the implicit links between the PR decisions and the effectiveness of company's operations.

Keywords: public relations, effectiveness of public relations, effectiveness evaluation, effectiveness evaluation criteria.

\section{Introduction}

Long-term success of the company and growth of competitiveness nowadays cannot be envisaged without public relations (PR). They are considered to be essential when creating the corporate image, enhancing the name awareness, supporting marketing programs, dealing with the issues arising at the time of crisis and activating the business (Cutlip et al., 2000; Zailskaite and Stravinskiene; 2008, Valackiene, 2010). PR are particularly contributing to building up trust in the company. It is, therefore, natural that business companies feel the need for PR development. Each activity in business companies, where PR do not constitute an exception, has to justify its existence and prove its purposefulness. Due to this, accountability of activities becomes important, whereas the instruments of measurement gain strategic relevance. Systemic and consistent evaluation of PR effectiveness represents an excellent option for solving of the mentioned issues, seeing as it allows substantiating the expedience of PR decisions. Complex nature of PR effectiveness evaluation (from the beginning to the end of PR program) allows evaluating and adjusting the actions in different stages of PR program: planning, implementation and evaluation (Kazokiene, Stravinskiene, 2007). Evaluation of elements that are linked in terms of process permits forgoing irrational decisions in ongoing programs and obtaining a better outcome.

Scientific literature contains quite many recommendations on PR effectiveness evaluation (Hon, 1998; Cutlip et al., 2000; Gregory, 2001). These are sufficiently clearly illustrative of the variety of PR effectiveness evaluation approaches and constitute a conceptual basis for the studies of this nature. Due to a rapid development of $\mathrm{PR}$, new aspects emerge that have not been considered in existing recommendations. It has been noted that many scientific works and recommendations on the issues of PR effectiveness evaluation do not satisfy the existing need to link the PR results with the corporate results (Noble, 1999). Many of the suggested measures for PR effectiveness evaluation are oriented to the evaluation of efforts of specific communication. They lack the corpus of clearly indicated evaluation criteria and systemic approach to PR effectiveness evaluation that would collate the value of PR decisions in the short- and long-term perspective (Kazokiene \& Stravinskiene, 2009). The adaptability of such measures becomes insufficient to emphasize the expedience of PR decisions.

It is the substantiation of such evaluation criteria permitting consistent and persistent evaluation of PR effectiveness and proving the expedience of PR decisions that constitutes the scientific problem examined in this article. 
The aim of the article is to establish the criteria for complex evaluation of PR effectiveness in business companies. Subject of research - PR effectiveness evaluation criteria. Methods of research - comparative, logical and resumptive analysis of scientific literature, quantitative and qualitative analysis of empirical data.

\section{Conceptual framework}

Interpretation of the general idea of PR effectiveness depends on the selected PR object and aim of research. After summarizing scientific approaches based on different theories, PR effectiveness is described as the value of $P R$ decisions to the company, expressed through the effectiveness of PR programs (comparing the set target to the obtained result) as well as the progress of company's relationships with strategic audiences (Kazokiene, Stravinskiene, 2009). The suggested notion of PR effectiveness:

emphasizes the value of PR decisions to the company in terms of relationships,

names the main features of PR effectiveness such as multiplicity and hierarchical composition of results,

stipulates the evaluation method;

integrates PR effectiveness on different levels program and corporate (thus permitting to perceive PR activities as the entirety of programs).

The stated insights permit suggesting that the presented PR effectiveness notion complies with the changed evaluation paradigm, highlighting the need for complex evaluation of PR effectiveness that is based on a chain reaction of the results of different process stages. Supporting the view that PR effectiveness evaluation should be of a complex nature, the need to identify elements comprising this complex becomes obvious.

The identification is made more difficult due to the absence of the uniform terminology of elements. The identicalness of elements in PR effectiveness evaluation constructs can be derived from submitted examples or explanations of individual elements. In the mentioned constructs, the following elements are designated as predominant ones: PR objectives, quality of communication messages, PR outputs, outtakes and outcomes (Kazokiene and Stravinskiene, 2009).

PR objectives determine a further direction of an action, and a suitably formulated objective, therefore, guarantees the success of the entire program. The necessity for the evaluation of PR objective is also included in PR effectiveness evaluation principles.

Quality of communication messages is associated with the message content and its suitability for the the audience (Swinehart, 1979; Bissland, 1990; Gregory, 2001). Phillips (2001) observed that the notion of communication messages' quality is significantly broader than the clarity of messages and suitability for audience. It may also include linguistic assessment (e.g., morphologic, syntactic or semantic). Despite intense efforts, the development of linguistic evaluation methods is still in a experimental stage. Due to the absence of adequate measures for establishing the quality of communication messages, it has been restricted to the content of communication message. According to Cutlip et al. (2000), Seitel (2001), the dissemination of communication messages represent some of the efforts for coordinating the communication program with the audience, helping to establish the adequacy of messages to the set objectives and having impact on the outcomes of PR programs. Janonis et al. (2007) noted that the selected method of communication is descriptive of the sender, source, recipient and relationships to be created between them. The belief expressed by the authors leads to the assumption that communication messages and their presentation should be included in the complex of PR effectiveness evaluation.

Other mentioned elements of evaluation - PR outputs and outtakes - are reflected in interpretations of PR effectiveness evaluation notion suggested by many scientists (Bissland, 1990; Gregory, 2001; Lindenmann, 2003). This implies that there is a consensus between scientists on PR outputs and outtakes. The need to evaluate PR outputs is predicated on the possibility to establish the outputs of PR specialists and to characterize the PR tactics (Cutlip et al., 2000). Evaluation of PR outtakes is the initial stage of PR impact evaluation, linking the PR actions and the target audience. It reveals the suitability of implemented tactical actions. PR outcomes are focused on deeper cognition that forms beliefs, attitudes and finally conative behavior. These represent an important datum level when assessing the attainment of the set objective. Furthermore, it may lead to the creation of new PR programs or further development of those already implemented. This belief is formed considering that the PR objective is formulated based on the results of environment studies as well as on the results of previous periods.

It is noteworthy that no element describing financial expenditures has been included in the complex of PR effectiveness evaluation. This decision is explained by the fact that financial assessment of PR does not always permit evaluating its effectiveness (Macnamara, 1999). Moreover, transmission of messages via cheap, but not always effective means encourages morally irresponsible behavior of specialists (Macnamara, 2000).

Efforts to suitably familiarize with the PR effectiveness evaluation process and find out the consistency of the identified elements of evaluation are based upon examples of recommended PR effectiveness evaluation models. It has been observed that known models by Cutlip et al. (2000), Macnamara (1999) distinguish between the stages of input, implementation and impact evaluation. Following logical consistency, it is to be believed that the first stage is described by PR objective, the second - by communication messages and their presentation. The last - impact - stage should encompass all possible PR results, i.e., PR outputs, outtakes and outcomes.

Following the defined consistency, further in the article criteria for PR effectiveness evaluation are theoretically substantiated.

\section{First stage of PR effectiveness evaluation}

\section{Criteria for PR objective evaluation}

Scientific literature on PR issues distinguishes between several levels of PR objectives. Hierarchical structure of the objective comprises the overall objective, tasks, target audiences and action plan (Kazokiene, 2010). The overall objective is expressed in a generic form. Tasks specify the planned PR outtakes and outcomes as well as program implementation period. According to Anderson et al. 
(1999), planned results should be measurable. The measurability of planned results permits foreseeing the direction of objectives' implementation and facilitates the control of PR implementation as well as effectiveness evaluation (Ross, 1972; Hon, 1997; Kitchen, 1997; Macnamara, 1999; Wilcox et al., 2003; Daugherty 2003; Lindenmann et al., 2003). Although the need for measurability of anticipated results is obvious, scientific works lack more accurate naming of indicators or dimensions. This leads to the assumption that criteria for the evaluation of planned outcomes are the same as for the outcomes to be evaluated in impact stage. Cutlip et al. (2000) noted that the outcome is set with regard to each target audience. The cognition of audiences is one of the key conditions for the attainment of higher PR outcome. It has been observed that business companies pay the most attention to employees, customers and business companies partners and customers. When characterizing the features of the mentioned audiences, market segmentation criteria are invoked.

When defining target audience of customers (physical persons), demographic, geographic and psychographic criteria are generally applied. The use of demographic data in PR permits creating contra-intuitive plans of measures for raising of general public's awareness which are more expedient, significant and productive (Phillips, 2006). Hon (1998) explained the significance of demographic information in empirical arguments. She referred to the results of the research carried out in 1990 in the USA that disclosed the direct influence of demographic criteria of the target audience - gender, age, education, revenues, stage of life and family composition - on finding and assimilation of information. The importance of demographic criteria is also revealed by the findings of the research by Sirtautas and Sirtautienè (2009), bespeaking of addressee's age as one of the most important factors when creating target advertising. More comprehensively the features of the target audience are defined by geographic (region, country, population density) and psychographic criteria (lifestyle, social status, belonging to a social class) (Wilcox et al., 2003). Smith (2005) recommended supplementing the indicated evaluation criteria by the criterion of relationships with the company defined by the customer type: accidental/regular; current/potential; competitive/loyal. Hon and Grunig (1999), Smith (2005) stated that not every social group could affect the results of the company and its progress. Due to this, it is expedient to establish the significance of target audience to the company. In case of customers, it is mostly determined by the size of social group. According to Smith (2005), a large social group has substantial influence to the opinion of the entire general public, too. Moreover, it draws the attention of media and other social groups. The author emphasized that small audiences can also be significant because they may carry a substantial social weight and/or enjoy recognition in the society.

Seeking to define target audiences more accurately and to extend the evaluation of their features, situational theory (J. Grunig) is invoked. It declares that there exists an interrelationship between knowledge, attitude and behavior that depends on situational variables: problem recognition, referential factor restricting the problem recognition and involvement in problem-related activity. These situational variables are defined by the level of individual's involvement in problem situation. It is characterized by types of audience's communication behavior (All-Issue Publics, Apathetic Publics, Single- Issue Publics, HotIssue Publics) (Harisson, 2000). The type of audience reveals its communication activeness or passivity. Identification of the audience type allows taking into consideration the environment, in which PR are being implemented, and anticipating possible response of the audience to new information. Moreover, it permits quicker and more effective anticipation of concrete actions than in the case of following rules and standard operational procedures (Noble, 1999).

After systemizing the insights of scientists concerning evaluation of features of target audience - customers, we suggest the following criteria: demographic, psychographic, geographic, relationships with the company, significance and communication behavior.

Defining the target audience - other companies, their firmographic (statistical) criteria, such as the number of employees, duration of operation, annual turnover, form of ownership etc, are often invoked besides geographic criteria, specifying company's place and scope of operations. When evaluating features of the target audience - business companies, likewise in the case of customers (physical persons), significance criterion may be relevant. This insight is predicated on the assumption that position in the market describing companies' significance (e.g., leading, monopolistic etc) determines differing interest in their activities or the willingness to cooperate (Cutlip et al., 2000; Smith, 2005; Watson and Noble, 2007). Hence, the following criteria are suggested for the characterization of the features of the target audience - companies: geographic, firmographic and significance.

In case of the target audience - employees, criteria defining employment relationships could be significant, such as for instance, the duration of employment, level of responsibility, structural level characterized by employee's position, subordination and nature of employment relationships (permanent/ temporary) (Smith, 2005).

When evaluating the objective on the lowest level of hierarchy - action plan - one should consider PR outputs, communication measures and their implementation period. These measures could include media, social projects, image advocates and virtual communication. Their suitability for PR in scientific literature has not been adequately emphasized.

It may be stated that the evaluation of PR objective essentially complies with the general principles for an objective setting, such as stipulation of target audience, expected result and its attainment in advance. Seeking to comply with other principles for objective setting, such as clarity, reality and accessibility, a more comprehensive list of objective evaluation criteria is needed.

Second stage of PR effectiveness evaluation

In line with the above insights, in this stage, two elements will be evaluated: communication messages and their presentation. 


\section{Communication messages evaluation criteria}

The set PR objectives affect the development of communication messages. Evaluation of communication messages permits improving the style of the messages submitted and facilitates the message understanding. (Bissland, 1990; Cutlip et al., 2000; Seitel, 2001). Analyzing communication messages, Cutlip et al. (2000), Seitel (2001) distinguished between the evaluation of simplicity/complexity of text or message and convenience of a text reading and listening to it, which may be conducted following Gunning and Flesh's formulas. The calculated results are objective quantitative indicators defining one of the aspects of message style and imparting primary knowledge on understandability of the message to target audience. In order to ensure systemic monitoring of communication messages and to improve technical skills of specialists, it needs to be acknowledged that the evaluation of quantitative criteria does not suffice. A more thorough analysis of communication message is possible invoking qualitative criteria.

The key purpose of a communication message is to provide the audience with information value. Consequently, informativeness of communication message may be considered to be an important evaluation criterion. Informativeness is described by sequence of information presentation. On this, scientists opinions fundamentally do not differ. Cutlip et al., (2000), Seitel (2001) recommend to present the key facts and the key point of the message at the beginning of the message. Towards the end facts are presented consistently with descending importance. This recommendation is based on the fact that the most attention is paid to the information at the beginning of the message that conditions further response to it.

Media specialists particularly emphasize another purpose of communication message - to raise interest, to draw the attention of the target audience. From this point of view, the novelty of a communication message is important. It is described by the conflict and capturing of attention. In PR literature, conflict as a phenomenon has not been analyzed sufficiently thoroughly. In the context of human relations, conflict is reflected by differing opinions and growing tension. Attention is fuelled by the shaping of message, non-stereotypical approach, non-conventionality, links of information with the topicalities or events of the time (Cutlip et al., 2000, Seitel, 2001, Wilcox et al., 2003). The last ones mostly affect trademark awareness, image and identity (Navickas and Malakauskaite, 2007).

While recognizing that publicity of negative nature will not help attaining PR objectives, division of messages into positive, negative and neutral has become popular on practical level. In Macnamara's (2000) opinion, the tone of communication message may not be recognized as the objective criterion of message evaluation. This belief is supported by the lack of objective and adaptive evaluation indicators when establishing the nature of message coverage in the media.

Each professional activity upholds certain standards and rules. Ethical issues are particularly important to PR. In the current information age, society feels an increasingly greater need for transparency and accountability of activities as well as the tendency to publicly evaluate business decisions. PR specialists influence the market by formulating public opinion on different issues and the understanding of PR ethics and observance of moral norms should, therefore, constitute the fundaments of activities. It is to be believed that communication messages should be evaluated from the position of ethics. In line with the code of ethics of PR specialists, professional responsibility and responsibility against the public could be distinguished. The first is associated with the individual's right to information: a PR specialist undertakes to provide true and accurate information and avoids unfair competition. Responsibility against the public reflects common moral norms: integrity, propagation of social values, etc.

Based on the submitted insights, simplicity, informativeness, novelty and ethicality of communication message are suggested as the key evaluation criteria.

Evaluation criteria of communication message presentation

When analyzing sources on communication messages, it was noticed that their presentation is generally associated by the scientists with the media.

Cutlip et al. (2000), Wilcox et al., (2003) state that the evaluation of attractiveness of the media and presentation of a communication message permit anticipating the potential and existing audience. When evaluating the attractiveness of media Cutlip et al. (2000), Seitel (2001) recommended evaluating the run of the media as well as rating, field of specialization, geographical coverage expressed in terms of local, national or international scope.

Generally, this kind of information is public and allows stipulating potential audience. When analyzing the attractiveness of communication message presentation, it is recommended taking into account the type of presentation (e.g., editorial, running line, etc.), time of broadcasting, date and place within a publication.

It can be stated that evaluation of message presentation is associated with criteria characterizing the communications channel.

\section{Third stage of PR effectiveness evaluation}

In the last stage of PR effectiveness evaluation, attention is drawn to PR outputs, outtakes and outcomes.

\section{PR outputs evaluation criteria}

In scientific literature on communications, PR outputs are identified with quickly-reachable results when publicizing communication messages. Mostly PR outputs are evaluated through monitoring of news releases, letters and articles. PR outputs evaluation helps avoiding methodic errors in carrying out the PR program. PR outputs' evaluation reveals resources and methods used, justifies the suitability of communication technique (Macnamara, 1999), defines potential audience (Cutlip et al., 2000) and informs on productiveness and scope of creative work of PR specialists (Wilcox et al., 2003). This kind of evaluation fosters the initiative of PR specialists and represents a tangible criterion for the evaluation of their performance.

Lindenmann (1993), Cutlip et al. (2000) recommend monitoring the audience's response and calculating the number of visitors in special events, for example, conferences or exhibitions, as well as number of visits in the company's website, volume of information copied from the website, frequency, time spent, number of people who filled company's questionnaires, visitors in forums 
who sent any kind of enquiries to the company, copied or downloaded company's material. Low activity bespeaks of unsuitable popularization.

Summarising the ideas of Lindenmann (1993), Macnamara, (1999), Cutlip et al. (2000), Wilcox et al. (2003), it can be concluded that for PR outputs' evaluation, criterion of communication messages' dissemination suffices. It is defined as the number of transmitted and/or written messages and audience's response, which is assessed in terms of the number of visitors in the company's website, respondents of company's questionnaires etc.

PR outtakes' evaluation criteria

PR effectiveness evaluation principles (Lindenmann et al., 2003) emphasize the differentiation of PR outtakes and outcomes. PR outtakes refer to an element of PR effectiveness evaluation complex that, compared to others, is new, lacking exhaustive description and often identified with PR outcomes. The existing dualism of PR outtakes' perception results in the difficulty to concretize PR outtakes and outcomes as well as their criteria. Due to this, hierarchy of objectives is followed. After adapting it for PR, Watson and Noble (2007) stipulated the following sequence of outcomes: to inform, encourage or motivate, affect or change the behavior of audience. Consequently, the primary result of PR should be associated with the cognition of phenomenon or object and should be directed towards increasing of target audience's awareness.

According to Smith (2005), evaluation of PR outtakes permits identifying target audiences reached by communication message and their response to information provided. Interpreting the recommendations of Noble (1999), Cutlip et al. (2000), Wilcox et al., (2003), Lindenmann et al. (2003), the target audience awareness is determined firstly by identifying the reached share of target audience and its reaction to communication message, afterwards finding out about the assimilation of information. According to the recommendations of Cutlip et al. (2000), Wilcox et al. (2003), according to share of target audience, different types of audiences may be distinguished, which:

- received the communication message (so-called reached audiences),

- memorized the communication message in any form,

- understood the communication message.

Understanding of communication message is described by the volume of accepted information, i.e., whether entire message or just a part thereof has been studied. In this kind of context, understanding of communication message is identified with awareness.

PR outtakes' evaluation represents the initial stage of PR impact assessment, linking PR actions with the target audience. It reveals the suitability of tactical actions implemented and, as appropriate, creates the conditions for avoiding undesired PR outcomes on a higher level. The stated insights imply the importance of target audience awareness criterion in the evaluation of PR outtakes.

\section{PR outcomes' evaluation criteria}

Based on the hierarchical system of objectives, further PR results are directed towards deeper cognition that shapes the beliefs and finally - the conative behavior. In this research, these results are identified with PR outcomes.
Generally business companies seek to deepen the knowledge of target audience about the company and its products. Communication messages usually inform about corporate events such as annual profit from operations, cooperation, achievements or awards gained during the current year etc. (Seitel 2001). In the reviewed scientific literature, no recommendations for evaluation of specific audience's knowledge are suggested. This is associated with different issues that are important to companies. Mostly PR efforts are focused on winning the public's trust in the company and its products or services. One can only assume that the change of knowledge can be defined by the levels describing their content.

When shaping the opinion of public audience and examining it Cutlip et al. (2000) foresee two options. In one case, evaluation of the opinion tone is possible. Based on subjective criteria, the opinion of target audience could be favorable or unfavorable to the company. The opinion can be in turn described as positive, neutral or negative. It should be emphasized that the evaluation of opinion tone based on subjective criteria cannot reveal small changes and should, therefore, be made more accurate. In the other case, more thorough analysis is recommended that defines the quality of opinion. Opinion quality evaluation includes: intensity of target audience's opinion, change of stability, maintenance of informativeness and support of the public (Cutlip et al., 2000). The criterion of opinion intensity reveals the strength of opinion. Intensity examination provides an initial assessment explaining the depth of respondents' conviction. Stability of opinion reveals the duration for how long the same opinion is being maintained and further intentions to change it. Informativeness maintenance evaluation describes the scope and quality of target audience's knowledge forming its opinion on a specific object. Evaluation of public's support reveals the correspondence of respondent's opinion to the opinions of other respondents in the same social environment.

Evaluating PR outputs and the change of knowledge or opinion, PR specialists can establish the effectiveness of a specific PR program or concrete case. Such evaluation has its limitations, because it does not reveal the PR value to the company (Hon and Grunig, 1999).

Supporting theoretical assumptions that perspectives of relationship management can comprise the grounds for PR theory and practice (Hon and Grunig, 1999; Ledingham 2010) and considering the fact that relationships affect the formation of public opinion and behavior intentions (Hon and Jung Ki, 2007) PR outcomes are referred to as the relationships of the company with its strategic audiences. High quality of relationships between the company and its strategic audiences is the primary precondition for the effectiveness of company's activities. While helping the company to develop relationships with strategic audiences, PR contribute to saving of company's finances: number of boycotts, internal regulation and pressure decreases. Good relationships with employees increase the probability that they will be loyal to and satisfied with the company (Ledingham and Bruning, 2000). Building of partnerships with all shareholders grants to the company additional opportunities and competitive advantage. Such relationships enhance the organization's stability, possibilities to 
manage volatile situations, its efficiency and competence (Svendsen, 1998). Besides enhanced performance of the organization and harmony of relationships, this holistic approach permits the organization to obtain a synergic effect, when favorable relationships with one group of shareholders, for example, community, start making a positive effect on another group of shareholders, for instance, customers (Susniene, Vanagas, 2006). Inclusion of a relationship factor in the PR effectiveness evaluation process integrates the PR achievements in the entirety of company's activities and substantiates the significance of PR objectives to the company. According to the research findings of Hon and Grunig (1999), relationships are described by their quality, which in turn is defined by:

- criterion of mutual trust. It is named as the key criterion in relationship evaluation, because there are no relationships without trust. Trust is defined by conviction, which is detailed by integrity, reliability and competence (Atkinson and Butcher, 2003; Patrick, 2004, Welch, 2006);

- criterion of mutual satisfaction. It is described as the level of benevolence towards each other. Satisfaction may also be expressed through the support of partner's behavior (Hon and Grunig, 1999). Dovaliene et al. (2007) stated that referrals of the company or its products are among the criteria describing satisfaction;

- criterion of mutual commitment. It is described by the continuity of a specific action. Ledingham et al. (1999) stated that commitment included the resolution to continue relationships. This implies that problems are used as opportunities to undertake joint efforts to solve them and to strengthen the relationships instead construing them as excuse to terminate the relationship. This criterion may also be associated with emotions (Hon and Grunig, 1999, Urboniene, 2007);

- criterion of mutual control. It describes the balance of power between the company and its audience or opponent, which is defined as the mutually agreed extent to which they can influence each other;

- criterion of relationship maturity. It is described by exchange and collective relationships. In exchange relationships, one of the partners provides benefit to another only due to the reason that the latter was useful to him in the past and is expected to be useful in the future. In collective relationships company or society provide benefit one to another only because they care about partner's welfare even without getting anything in return. Collective relationships differentiate the PR outcome - change of relationships from the change of relationships based upon marketing expenses and benefit obtained. Due to this, collective relationships should be considered significant when showing the role and potential value of PR. The above-mentioned criterion of relationship quality are characteristic to the collective as well as exchange relationships; it is only the degree of their intensity that varies. It is to be believed that due to high subjectivity there are no concrete references as to the intensity degrees to be ascribed to exchange and collective relationships.

After summarizing the scientists' approaches to $P R$ effectiveness evaluation, it is recommended to commence the $P R$ effectiveness evaluation from $P R$ objectives while evaluating planned $P R$ results, features of target audience and program implementation period. It is further suggested to consistently evaluate communication messages and their presentation, in the case of communication messages focusing on their simplicity, informativeness, novelty and ethicality. In the case of message presentation the focus should be placed on attractiveness of media and presentation of communication message. In the final stageimpact evaluation - PR outputs' evaluation is recommended, which is described by dissemination of communication messages and audience response, and PR outtakes' evaluation that is defined by the awareness of the target audience. Furthermore, in this stage, the evaluation criteria of target audience's knowledge, opinion and relationships are taken into account. These in particular allow associating $P R$ decisions with overall corporate objectives.

\section{Research methodology}

Seeking to identify PR effectiveness evaluation criteria and outline more accurately the PR effectiveness evaluation process, an empirical research was carried out. In the research, the methodology integrating the findings of quantitative and qualitative research was applied. This decision was determined by traditions existing in PR for the application of different methodological approaches as well as the level of the theoretical and practical examination of a problem issue. Due to the lack of clear initial information, qualitative research was selected for PR objectives' evaluation process. The abundance of scientific studies and comprehensive theoretical fundaments on PR implementation and impact evaluation determined the selection of quantitative research.

Structured interview form of expert evaluation was invoked to substantiate the PR objective evaluation criteria. This form is broadly applied in social studies. When processing the data of qualitative research, content analysis and hermeneutical approach were combined, enabling a more accurate recreation of experts' assessments on the evaluation of PR objectives.

When establishing the sample of a qualitative research, the aim was to select such cases, which are informative in terms of a research perspective. Due to this, mixed target sampling was applied, encompassing several methods of a research sample compilation. In the case of experts, screening methods of selection according to criteria and snowball have been applied. The group of experts comprised representatives of 12 business companies and 8 specialized agencies possessing experience in the formulation and evaluation of PR objectives. The content of a structured interview plan was linked with the PR evaluation criteria established based on theoretical studies. In total, the structured interview plan comprised 20 open questions, allowing the informant to give answers freely. The reliability of qualitative research instrument was verified by invoking innovative methods and calculating Cronbach's alpha coefficient. Cronbach's alpha was calculated based on methods for quantification of qualitative data prepared by Vaitkevicius (2010) and aimed at quantitative comparison of qualitative and quantitative data. Reliability coefficient of the instrument is high ( $\alpha$ varies from 0.61 to 0.907$)$. 
Questionnaire survey was invoked to substantiate the evaluation criteria for PR implementation and impact stages. It allowed the insight into common tendencies and establishment of the dispersion of opinions within population. Respondents were selected by a nonprobabilistic method for a target group formation. It is noteworthy that sample comprised two different groups of respondents: representatives of business companies $(\mathrm{N}=83)$ and experts $(\mathrm{N}=16)$. This decision is construed as different data collection methods contributing to the ensuring of the objectivity of results. Divergence of opinions or distortion of results were not recorded by either reliability or factor analysis.

The content of the questionnaire was associated with the criteria for PR implementation and impact evaluation stages, established basing on theoretical studies. Moreover, when formulating questions pertaining to the significance of criterion of relationship quality for the evaluation of PR outcomes, research instruments of Hon and Grunig (1999), Rawlins (2008) were invoked, while interpreting them and adapting for the research in PR effectiveness evaluation context. In the questionnaire, research scales were constructed aimed at finding out: 1) respondents' opinion and 2) respondents' practice in the field of PR implementation and impact evaluation. This decision was determined by the assumption that respondents, when expressing their opinion, tend to somewhat hyperbolize it. When building the scales of respondents' opinion and practice, 7 blocks of questions were compiled on PR implementation and 10 on PR impact, making a total of 96 (+96) questions.

For processing of the data of quantitative research $(\mathrm{N}=$ 99) factor, reliability and regression analyses were used.

After conducting the factor analysis, the grouping of variables was defined more accurately and reliability of instrument was confirmed. Elements describing PR implementation were conditionally named as follows: simplicity, informativeness, veracity, ethicality and novelty of communication message, attractiveness of media, attractiveness of message presentation. Elements describing PR impact were termed as follows: attention of the audience, awareness, change of knowledge and opinion, mutual trust, satisfaction, control, commitment, exchange and collective relationships.

Calculated KMO values show that the factor analysis of variables under consideration has been useful. It was determined that the scale of respondents' opinion and practice comply with content validity requirements. Findings of factor analysis allowed stating that interpretation of research findings is substantiated and reliable. Statistical correlations between attributes are sufficiently strong. Statistical association of test steps with the factors is theoretically meaningful. Internal consistency of factors, evaluated by Cronbach's alpha, is not below 0.5 . All obtained factors are sufficiently homogenous.

Quantitative and qualitative research methods are based on the findings of theoretical studies and key recommendations for the preparation of researches of this kind, allowing to judge on possible formulation of substantiated research conclusions.

\section{Results}

PR input stage evaluation criteria

Seeing that the overall objective of PR is of generic nature, evaluation is commenced from tasks.

In this case, it is recommended evaluating the implementation period of planned PR program and anticipated PR results (change of knowledge, opinion, sequence of priority). When defining more accurately the evaluation criteria of PR implementation period on a task level, it turned out that in the characterization of program implementation duration it is worthwhile to focus on minimal and maximal periods needed to obtain the planned result, the limits of which are conditionally determined by practical experience. Systemized criteria for PR objective evaluation are presented in Table 1.

To define all PR outcomes, i.e., change of knowledge, opinion, sequence of priority, quantitative criteria are used: percental or relative share of target audience compared to competitors. Moreover, when describing the expected change of opinion, the following quantitative criteria can be distinguished:

- opinion tone: positive, neutral, negative. When studying this phenomenon, the necessity for grading of favorable and unfavorable opinion emerged. Based on hedging and wedging theory, only gradual change of opinion is possible and after introducing a degree unit of opinion tone, detection of even a slight change of opinion is, therefore, feasible, when comparing the results before and after the program implementation;

- degree of customer satisfaction; this criterion is possible in PR programs; however, it is not as frequent and popular as in other programs, e.g., marketing.

According to experts, planned change of opinion can also be described using qualitative criteria. Content of values positioned by the company refers to one of them. Positioned feature of company or product is described by specific indicators, which have clear links with positioning direction stipulated in the overall objective. In line with those, opinion being shaped is described. For instance, if the company seeks to form an image of company - partner, then, subject to values fostered by the company, the conception of partnership is elaborated. Depending on the overall PR objective, another alternative criterion for the evaluation of an opinion change can be selected - opinion quality. Evaluation of this criterion can be expedient in the case when target audience represents entire society.

According to experts, an expected change of knowledge, besides the mentioned criterion of relative share of target audience, in tasks may also be described by splitting knowledge into levels. Two levels are distinguished:

- $\quad$ primary (basic) knowledge level includes the main information about the company, product, category of products and is associated with spontaneous awareness. In other words this refers to the awareness of the existence of the product or company in the market;

- knowledge of educational level usually refers to the nature and peculiarities of company's activities, positive and negative features of a product. 
Lina Kazokiene, Jurgita Stravinskiene. Criteria for the Evaluation of Public Relations Effectiveness

Table 1

PR objectives' evaluation criteria

\begin{tabular}{|c|c|c|c|c|c|}
\hline Level & Object & luation & Criteria & & Indicators \\
\hline \multirow{9}{*}{ Tasks } & \multicolumn{2}{|c|}{ Implementation period } & \multicolumn{2}{|l|}{ Duration } & Minimal, maximal \\
\hline & \multirow[t]{8}{*}{$\begin{array}{l}\text { Planned PR } \\
\text { outcome }\end{array}$} & $\begin{array}{l}\text { Sequence } \\
\text { of priority }\end{array}$ & Quantitative & $\begin{array}{l}\text { Share of target } \\
\text { audience }\end{array}$ & $\begin{array}{l}\text { a) Share of target audience in per cent, b) relative share of } \\
\text { target audience. }\end{array}$ \\
\hline & & \multirow[t]{2}{*}{$\begin{array}{l}\text { Change of } \\
\text { knowledge }\end{array}$} & Quantitative & $\begin{array}{l}\text { Share of target } \\
\text { audience }\end{array}$ & $\begin{array}{l}\text { a) Share of target audience in per cent, b) relative share of } \\
\text { target audience. }\end{array}$ \\
\hline & & & Qualitative & Knowledge levels & Basic, educational \\
\hline & & \multirow[t]{5}{*}{$\begin{array}{l}\text { Change of } \\
\text { opinion }\end{array}$} & \multirow{3}{*}{ Quantitative } & $\begin{array}{l}\text { Share of target } \\
\text { audience }\end{array}$ & $\begin{array}{l}\text { a) Share of target audience e in per cent, b) relative share of } \\
\text { target audience. }\end{array}$ \\
\hline & & & & Opinion tone & Degree of opinion (non)benevolence \\
\hline & & & & Customer satisfaction & Degree of customer satisfaction \\
\hline & & & \multirow[t]{2}{*}{ Qualitative } & Opinion quality & $\begin{array}{l}\text { Intensity of opinion, stability of opinion, maintenance of } \\
\text { informativeness, support to the public }\end{array}$ \\
\hline & & & & $\begin{array}{l}\text { Content of positioned } \\
\text { values }\end{array}$ & Features with which the company identifies \\
\hline \multirow{18}{*}{$\begin{array}{l}\text { Target } \\
\text { audience }\end{array}$} & \multirow{8}{*}{\multicolumn{2}{|c|}{$\begin{array}{l}\text { Features of customers } \\
\text { (physical persons) }\end{array}$}} & \multicolumn{2}{|l|}{ Geographic } & Customers' place of residence \\
\hline & & & \multicolumn{2}{|l|}{ Psychographic } & $\begin{array}{l}\text { a) area of activities/interests, b) purchasing/consumption } \\
\text { model, c) likings, d) social roles, e) way of living }\end{array}$ \\
\hline & & & \multicolumn{2}{|l|}{ Demographic } & $\begin{array}{l}\text { a) age, b) gender, c) family composition, d) income, e) } \\
\text { education }\end{array}$ \\
\hline & & & \multicolumn{2}{|c|}{ Relationships with the company } & $\begin{array}{l}\text { a) potential/current; b) loyal/competitive, c) fans (or } \\
\text { supporters), d) in doubt (or undecided) }\end{array}$ \\
\hline & & & \multicolumn{2}{|c|}{ Communication behavior } & a) active/passive, b) receptive to information \\
\hline & & & \multicolumn{2}{|c|}{ Method for formation of understanding } & $\begin{array}{l}\text { a) particularities associated with searching for information, } \\
\text { b) customer's referential group }\end{array}$ \\
\hline & & & \multicolumn{2}{|l|}{ Significance } & a) size of social group \\
\hline & & & \multicolumn{2}{|l|}{ Ethnic } & a) cultural values and peculiarities \\
\hline & \multirow{3}{*}{\multicolumn{2}{|c|}{ Features of employees }} & \multicolumn{2}{|l|}{ Demographic } & a) family composition \\
\hline & & & \multicolumn{2}{|c|}{ Nature of work } & $\begin{array}{l}\text { a) subordination, b) position, c) nature of employment } \\
\text { relationships, d) field of work, e) duration of employment. }\end{array}$ \\
\hline & & & \multicolumn{2}{|l|}{ Geographic } & a) regional structure, b) place of work (mobility) \\
\hline & \multirow{2}{*}{\multicolumn{2}{|c|}{$\begin{array}{l}\text { Features of business } \\
\text { companies - customers }\end{array}$}} & \multicolumn{2}{|c|}{ Psychographic } & a) type of purchasing and consumption behavior \\
\hline & & & \multicolumn{2}{|c|}{ Method for formation of understanding } & a) particularities associated with searching for information \\
\hline & & \multirow{5}{*}{$\begin{array}{l}\text { Features } \\
\text { of } \\
\text { business } \\
\text { companies } \\
\text { - partners }\end{array}$} & \multicolumn{2}{|l|}{ Significance } & a) position in the market b) social weight in the market \\
\hline & & & \multicolumn{2}{|l|}{ Firmographic } & a) field of activities, b) annual turnover, c) company size \\
\hline & & & Relationships & company & a) current/potential, b) duration \\
\hline & & & Characteristic & any's representative & a) representative's position \\
\hline & & & Geographic & & a) place of operations \\
\hline $\begin{array}{l}\text { Action } \\
\text { plan }\end{array}$ & Planned PR & & $\begin{array}{l}\text { Dissemination } \\
\text { information }\end{array}$ & munication messages / & $\begin{array}{l}\text { a) no. of messages, b) no. of references to the company in } \\
\text { media, c) no. of favorable/negative/neutral articles about } \\
\text { the company, d) no. of events }\end{array}$ \\
\hline & & & Content of cor & ation messages & $\begin{array}{l}\text { a) topics under which the company was mentioned or its } \\
\text { representatives quoted, b) tone/benevolence of article about } \\
\text { the company }\end{array}$ \\
\hline & & & Potentially rea & dience & Part of potential audience \\
\hline & Communicat & leasures & & & \\
\hline & 1. Soc. proje & & Suitability of & sure & $\begin{array}{l}\text { a) originality, b) significance to the society, c) alignment } \\
\text { with the company's general policy, d) alignment with the } \\
\text { concept of product, e) continuity, f) usefulness to the } \\
\text { company, g) permanent value, h) consistency }\end{array}$ \\
\hline & 2. Person/im & dvocates & & & a) trust in the person, b) competence \\
\hline & 3. Mentoring & & & & a) significance to the public - not to be evaluated \\
\hline & $\begin{array}{l}\text { 4. Media (in } \\
\text { articles) }\end{array}$ & of ordered & & & $\begin{array}{l}\text { a) geographic accessibility, b) specialization, c) run, d) } \\
\text { reader's profile }\end{array}$ \\
\hline & 5. Virtual co & nication & & & Color and psychological alignment with company's actions \\
\hline
\end{tabular}


In experts' opinion, the change of knowledge in rapidly-developing situations, for instance, upon occurrence of unforeseen events, may be non-formalized.

While identifying the evaluation criteria of main the target audiences of business companies, it became obvious that the completeness of their description is determined by the measures of communication and the content of information.

Comprehensive description of target audience's features is relevant in the case of direct contact communication or when using social media. From the information content point of view, target audience is described the most comprehensively when communicating messages about the product.

After calculating the relative frequency of repetitions of extracted categories, it was determined that in the evaluation of features of business companies - customers, firmographic criteria are mostly taken into account (25\%). Among those, field of activity of business company customer is predominant $(50 \%)$. It is noteworthy that in the case of business companies - customers, significance criterion is as much important as firmographic. Among those, the most attention is paid to indicators describing the market position of business companies - customers. Geographic criteria (16.67\%) can also be considered as rather important when describing the audience of business companies - customers. Although geographical aspect is defined by the place of operations only, it ought to be emphasized that geographic criteria might be important and evaluated in the context of distance as well as specifics of the product and customer concentration. Besides the mentioned criteria, positions of business companies' representatives are also evaluated. When analyzing evaluation criteria of business companies- customers with the highest frequency of repetitions, it was noticed that the evaluation criteria of the features of business companies customers which are associated with the product and describe the attractiveness of the buyer are to be considered as more important.

When analyzing the frequencies of relative repetitions in the case of business companies - partners, it was observed that firmographic criteria are mostly taken into account $(44.44 \%)$. In this case, economic indicators and the size of the partner are important. Geographic and significance evaluation criteria can be considered as equally important (22.22\% each). Among those, partner's weight in the market and possible influence to the company (50\% each) are taken into account. While interpreting the findings, we state that evaluation criteria of partners' features in general terms describe the attractiveness of cooperation.

When examining the evaluation criteria of customers (physical persons), it was determined that most often demographic criteria are invoked (42.50 \%). Among demographic criteria, age, income and gender are noted for higher relative frequency of repetition. Findings of qualitative research imply that business companies orient themselves to the segment that is the most profitable in their opinion. Geographic criteria should also be considered as important $(23.60 \%)$, and they define the customers' place of residence. It is to be believed that evaluation of geographic criteria first of all is associated with the purchasing potential and need for certain products. Other group of customer features' evaluation criteria to be considered as relatively important are psychographic (19.5 $\%$ ). In this group, according to relative frequency of repetitions, field of activity and interests, consumption and purchasing model, likings and leisure distribute equally. The listed criteria are perhaps the most associated with the product communication. In practice, evaluation criterion of relationships with the company is encountered rather less frequently than demographic or psychographic. Relative frequency of repetitions implies that generally customers are divided into current and potential.

Based on the frequency of repetitions of extracted categories, in the case of target audience - customers and companies - customers and partners, criteria of communication behavior, understanding formation method and ethnic criteria are considered to be less important.

Analysis findings of repetition frequency of evaluation criteria of target audience - employees revealed that mostly in practice there are used evaluation criteria of the nature of work. The need for division of employees by subordination, positions or field of work is determined by the need for different information for performance of work. Besides the mentioned criteria, experts see the possibility to take the nature of employment into account: permanent or temporary. It is likely that geographic and demographic criteria are less often used in practice when evaluating the features of employees. Such a lack of popularity might be associated with the avoidance of discrimination. This explains the fact that family composition is the only demographic criteria, describing employees' features. The need for its evaluation arises from searching for original solutions when carrying out indirect communication. The accumulated data on evaluation of geographic criteria enabled observing that place of work (stationary or mobile) often determines the measures used to convey information or its form and consequently the necessity appears to evaluate the mobility of employee's workplace.

In the hierarchically lowest level - action plan evaluation concerns planned PR outputs and communication measures. When evaluating the planned outputs of PR, the most attention is paid to dissemination and content of communication messages. The least attention - to audience potentially reached. The selection of evaluation criteria for PR outputs stipulated in the objective may be determined by several reasons. One of them - tendency of the company to formalize its actions while leaving to employees little freedom for interpretation.

When evaluating the means of communication, their suitability for implementation of specific program is taken into account. It was noticed that suitability of social projects is described by the significance of the project to the society. Furthermore, much attention is paid to originality of the social project. Besides those, compatibility of the social project with the overall corporate policy is also worth emphasizing. This implies that social projects undergoing implementation should always be based on the values upheld and fostered in the company. In line with the repetition frequency of extracted 
categories, compatibility of the project with the product concept, continuity, usefulness to the company, permanent value and consistency are less important criteria. When analyzing the evaluation of media suitability, the following indicators should be mentioned: geographic accessibility, specialization, run and reader's profile. It should be emphasized that action plan may stipulate and evaluate media in the case of ordered articles. Suitability of person/image advocate is described by the trust in that person and his/her competence. In the evaluation of virtual communication means, attention is paid to color and psychological alignment with the company's actions. Findings of expert evaluation of PR input stage provide new and interesting information on PR input evaluation. The analysis of the interview data enabled observing that in many cases experts' responses were predicated on skills and experience formed in practice. This means that more detailed cognition of evaluation criteria is possible while analyzing the experts themselves.

\section{criteria \\ PR implementation and impact stages' evaluation}

Interview data allowed expanding the cognition of PR effectiveness evaluation process while supplementing it with an interim evaluation stage and PR implementation and impact evaluation criteria, which were not included in the analyzed scientific insights. According to the experts, an interim evaluation stage succeeds the implementation evaluation. Subject to the company's resolution, it may consider some or all evaluation criteria of PR outputs and outtakes. Evaluation criteria for PR implementation and impact stages were presented after summarizing the findings of quantitative and qualitative researches. When summarizing the findings of quantitative research, percentage of mean approval of statements included in the scales was invoked.

\section{PR implementation evaluation criteria}

When analyzing the data of quantitative research that describe the PR implementation evaluation criteria, it was established that in the respondents' opinion the majority of those were important. This is shown by high percentage expression of approval (from 49.5 to $91.9 \%$ ). In the population of subjects, the strongest opinion was expressed on veracity of communication message $(91.9 \%)$. Compared to others, respondents approved less of message novelty evaluation $(49.5 \%)$. When analyzing the criteria evaluated by the respondents in practice, it was noted that among all evaluation criteria, novelty of the message $(23.2 \%)$ and attractiveness of the media $(43.4 \%)$ were taken into account the least. All other examined evaluation criteria of PR implementation should be construed as important. The majority of PR implementation evaluation criteria, comparing the respondents' opinion and practical activity, are rated similarly.

When interpreting the findings of PR implementation approvals, it can be generalized that the majority of the surveyed pay much attention to the criteria, which describe ongoing progress and the efforts of the employee him/herself. Evaluation criteria describing the ongoing progress and efforts of other persons, for instance, journalists, were approved of rather less. The likely cause is that the respondents were less familiar with the last criteria. Evaluation criteria of PR implementation that were subjected to quantitative research were supplemented with the criterion of purpose-centrality of information provided, established in the course of the research. Striving towards PR objectives, the representatives of companies must act in a coordinated manner and with one accord, and abstain from spreading contradicting information that negatively affects the attainment of objectives. Moreover, the findings of qualitative research enabled supplementing the indicators of established evaluation criteria (see Table 2). After carrying out the regression analysis, it was determined that in this stage the evaluation criteria of message veracity and media attractiveness are the most important, seeing as their impact on PR outcomes is the weightiest one. With media attractiveness rating increasing by one unit, impact evaluation increases by $68 \%$. When message veracity rating increases by one unit, impact strengthens by $38 \%$. The least significant are the evaluation criteria of informativeness and attractiveness of message presentation. The established evaluation criteria of PR implementation stage allow analyzing the presentation of information and assessing potential audience. This contributes to improvement of communication skills, enables noticing possible errors, in particular those associated with the purpose-centeredness of information.

Systemized evaluation criteria of PR implementation stage

\begin{tabular}{|l|c|}
\hline \multicolumn{1}{|c|}{ Criteria } & Indicators \\
\hline Message simplicity & Convenience of reading/listening to the text, complexity/simplicity of the text \\
\hline Message informativeness & Place where information is provided and succession \\
\hline Message veracity & Professional responsibility (indicators, veracity and accuracy of information) \\
\hline Message ethicality & Content unity of messages \\
\hline Purpose-centeredness of information provided & Conflict, attraction of attention \\
\hline Message novelty & Run, rating, level of geographic accessibility, field of specialization \\
\hline Attractiveness of the media & $\begin{array}{c}\text { Place in the publication, message transmission time, message transmission type, } \\
\text { transmission date, transmission context, representative of the media (author's } \\
\text { area of interests) }\end{array}$ \\
\hline Attractiveness of message presentation & \\
\hline
\end{tabular}




\section{PR impact evaluation criteria}

In the PR impact stage it is recommended to consid the criteria for the evaluation of PR outputs, outtakes and outcomes. When analyzing the PR impact evaluation criteria, it was observed that the respondents had the most distinctive opinion with regard to knowledge change evaluation criterion $(88.9 \%)$. The respondents approved the least of evaluation of exchange relationships (45.5\%).

In the case of PR impact evaluation, the number of those approving rather substantially differed in the case of opinion and practice. Opinion survey results allow stating that many of those surveyed agreed with all listed PR impact evaluation criteria. Findings of practice research show that in practice PR impact is evaluated less often as compared to the implementation evaluation. Findings of the research by companies' area of activities were the least coinciding in service and manufacturing companies; by the size of companies - in small companies. Respondents' opinion and practice concerning PR impact evaluation did not essentially differ in large companies. Evaluating by companies' area of activities - in sales companies (practice matched the opinion). It is believed that little attention to PR impact is paid by the companies, which are likely to encounter obstacles, e.g., shortage of financial funds or lack of specific knowledge. It would be worthwhile to mention separately micro-companies, the majority of which in this research were represented by people from PR agencies. Findings of the research show that they also perform PR impact evaluation rarely. This could be explained by the fact that they perform only the kind of evaluation ordered by the customer.

In line with the results of respondents' opinion, in PR impact evaluation stage all criteria identified in theoretical studies should be taken into account (see Table 3). It should be emphasized that the list of these criteria was supplemented with the evaluation criteria established during the qualitative research that had not been detected when analyzing scientific literature on PR. While analyzing the PR impact evaluation criteria identified during qualitative research, it was observed that PR outputs' evaluation expands in particular. Theoretical study allowed identifying the criteria defining PR outputs:

- dissemination of communication messages,

- response of the audience.

According to the findings of qualitative research, PR outputs' evaluation was supplemented with the following criteria:

- content of communication messages,

- reliability of company's representative,

- knowledge provided by the company and competitors,

- company's relative share compared to competitors.

The evaluation of communication messages' content allows a more comprehensive understanding of favorable or unfavorable appreciation of company's activity or product and indirectly points to problem areas, in which more active PR efforts are needed. Reliability of company's representative might be interesting to the companies that seek for recognized expert's position on the market. On the other hand, if there are several image advocates in the company, evaluation of this criterion helps balancing the performance of advocates' functions and avoiding one of them being predominant. Based on theoretical analysis of PR outputs, it can be seen that outputs are defined by the number of broadcasted or published messages, number of flyers distributed etc. Hence, share of potentially reached audience that is generally determined according to the run of publication is not an entirely new criterion. Here, new is the aspect that potentially reached audience is thoroughly examined and detailed by the type of communication means and topic providing to the audience knowledge in a specific field. Thorough study of potentially reached audience helps identifying more accurately the areas of communication that are of relevance to the company. Other two evaluation criteria of PR outputs are associated with the analysis of PR actions on the market. Evaluation of knowledge provided by the company and competitors and of relative part of the company compared to competitors allows observing the directions towards which rivaling companies direct their efforts and conduct a comparative analysis. Obtained results allow stating that PR outputs can be evaluated both quantitatively and qualitatively.

When evaluating PR outtakes, an evaluation criterion of target audience's awareness was substantiated. It is defined by the overall share of target audience reached and the share of the audience, which familiarized with the message.

PR outcomes were established following PR objectives that are encountered most frequently, i.e., development of relationships, formation of opinion, education and sequence of priority with regard to the company or its products (first choice). Findings of the research confirmed that change of knowledge of target audience might be evaluated while invoking the segmentation of knowledge into levels. Moreover, a quantitative criterion - reached share of target audience - may be used. Likewise in the case of the change of knowledge, for the evaluation of audience's change of opinion, quantitative and qualitative criteria may be invoked. In line with the findings of the research, the following criteria are recommended: content of positioned values, opinion quality, customer satisfaction, opinion tone and share of target audience. The latter is used for the evaluation of another PR result - sequence of priority. For the change of relationships, the use of criterion defining the quality of relationships in PR outputs' evaluation process was empirically confirmed.

When analyzing the evaluation criteria of PR outcomes, it was noted that respondents mostly approved of the change of knowledge criterion (88.9\%). Respondents approved the least of the evaluation of exchange relationships (45.5\%). When discussing the PR outcomes' evaluation criteria in an impact stage, it is worth mentioning that comparison of PR input and impact stage evaluations showed an obvious difference in evaluating PR outtakes: in the last stage, it is more comprehensive, encompasses more evaluation criteria.

It is to be believed that this difference appears due to ordered/not ordered messages. Contrary to not ordered messages, those ordered can be planned and controlled by the company. 
Lina Kazokiene, Jurgita Stravinskiene. Criteria for the Evaluation of Public Relations Effectiveness

In impact evaluation stage, there are substantially more criteria for the evaluation of PR outputs, depicting a more complete picture of primary results and characterizing the specialists' performance. This observation suggests that in PR input stage only the most relevant evaluation criteria of PR outputs are taken into account.

Table 3

Systemized criteria for PR impact evaluation

\begin{tabular}{|c|c|c|c|}
\hline \multicolumn{2}{|c|}{ Evaluation criteria } & \multicolumn{2}{|c|}{ Indicators } \\
\hline \multicolumn{4}{|c|}{ Evaluation of PR outputs } \\
\hline \multirow{4}{*}{$\begin{array}{l}\text { Attention of the } \\
\text { audience }\end{array}$} & \multirow{3}{*}{$\begin{array}{l}\text { Dissemination of } \\
\text { communication } \\
\text { messages / } \\
\text { company } \\
\text { information }\end{array}$} & \multicolumn{2}{|l|}{ Number of communication messages } \\
\hline & & \multicolumn{2}{|l|}{ No. of ordered / not ordered messages } \\
\hline & & \multicolumn{2}{|c|}{ Number of comments (e.g., in internet portals), positive / negative referrals } \\
\hline & $\begin{array}{l}\text { Response of the } \\
\text { audience }\end{array}$ & \multicolumn{2}{|l|}{ Any form of feedback, inquiries received } \\
\hline \multirow{3}{*}{\multicolumn{2}{|c|}{ Content of communication messages }} & \multicolumn{2}{|c|}{ Number of positive, negative, neutral referrals in information media } \\
\hline & & \multicolumn{2}{|c|}{ Tone/ benevolence of article with regard to the company } \\
\hline & & \multicolumn{2}{|c|}{$\begin{array}{l}\text { Subjects under which the company is mentioned or its representatives quoted (finance, } \\
\text { economics etc) }\end{array}$} \\
\hline \multirow{3}{*}{\multicolumn{2}{|c|}{$\begin{array}{l}\text { Reliability of company's representative } \\
\text { (value of opinion) }\end{array}$}} & \multicolumn{2}{|l|}{ Number of company representative's quotes } \\
\hline & & \multicolumn{2}{|c|}{ Number of company representative's speeches } \\
\hline & & \multicolumn{2}{|c|}{ Representatives of the company who were quoted the most often } \\
\hline \multirow{3}{*}{\multicolumn{2}{|c|}{ Potentially reached audience }} & Overall potentially reached audience & Quantity, number \\
\hline & & $\begin{array}{l}\text { Share of potentially reached audience by } \\
\text { subjects }\end{array}$ & $\begin{array}{l}\text { a) finance, b) economics, c) expert (expert } \\
\text { communication), d) product e) management }\end{array}$ \\
\hline & & $\begin{array}{l}\text { Share of potentially reached audience by } \\
\text { type of communication means }\end{array}$ & $\begin{array}{l}\text { a) media (in total), b) specialized publications, c) } \\
\text { leisure publications, d) radio, d) TV, e) regional } \\
\text { newspapers, f) national newspapers, g) internet }\end{array}$ \\
\hline \multirow{2}{*}{\multicolumn{2}{|c|}{$\begin{array}{c}\text { Knowledge provided by company and } \\
\text { competitors }\end{array}$}} & Content of positive knowledge & $\begin{array}{l}\text { a) existence of product, b) participation in } \\
\text { campaigns, projects prepared, c) internal changes } \\
\text { within the company, d) awards received }\end{array}$ \\
\hline & & Content of negative knowledge & $\begin{array}{l}\text { a) sanctions imposed, b) problems within the } \\
\text { company (e.g., lack of qualified specialists, c) } \\
\text { litigation, d) negative financial results }\end{array}$ \\
\hline \multirow{2}{*}{\multicolumn{2}{|c|}{$\begin{array}{l}\text { Relative share of the company compared } \\
\text { to competitors }\end{array}$}} & \multicolumn{2}{|l|}{ Relative share of referrals } \\
\hline & & \multicolumn{2}{|c|}{ Relative share of company's role (primary / secondary) } \\
\hline \multicolumn{4}{|c|}{ Evaluation of PR outtakes } \\
\hline \multirow{2}{*}{\multicolumn{2}{|c|}{ Target audience awareness }} & \multicolumn{2}{|c|}{ Total share of target audience reached (those who received the message) } \\
\hline & & \multicolumn{2}{|c|}{ Share of target audience who familiarized with the message (read / listened) } \\
\hline \multicolumn{4}{|c|}{ Evaluation of PR outcomes } \\
\hline & & a) evaluation of the change of knowl & \\
\hline Share of targe & dience reached & Share of target audience reached, in per c & \\
\hline & & Relative share of target audience reached & ipared to competition) \\
\hline Know & e levels & Basic and educational & \\
\hline & & b) evaluation of the change of opin & \\
\hline Content of position & alues & Features with which company is identifie & \\
\hline Quality of opinion & & Intensity of opinion, stability of opinion, & tenance of informativeness, support of the public \\
\hline Customer satisfact & & Degree of customer satisfaction & \\
\hline Tone of opinion & & Graded expression of opinion (un)favoral & \\
\hline Share of target aud & & Share of target audience in per cent, relat & are of target audience \\
\hline & & c) evaluation of sequence of prior & \\
\hline Share of target aud & & Share of target audience in per cent, relat & are of target audience \\
\hline & & d) evaluation of the change of relatio & \\
\hline Mutual trust & & Belief or trust indices & \\
\hline Mutual satisfaction & & Benevolence & \\
\hline Mutual commitme & & Continuity of action and emotions & \\
\hline Mutual control & & Balance of power & \\
\hline Santykių branda & & Mainų ir kolektyviniai santykiai & \\
\hline
\end{tabular}


In summary of the obtained results of $P R$ implementation and impact evaluation, it can be stated that the majority of those surveyed approve of evaluation of all criteria examined; however, in practice particularly small and medium companies are likely to encounter restrictions, e.g., shortage of financial funds or lack or specialist knowledge, which in turn determine the discrepancy between expressed opinion and practical actions.

\section{Conclusions}

PR effectiveness evaluation is a multi-plane object of studies: the notion of PR effectiveness is not unambiguous, whereas the evaluation process encompasses the program implementation from the beginning to the end.

PR effectiveness evaluation process is explicitly defined by its stages and elements evaluated therein, which are in turn described by concrete criteria. It was determined that PR effectiveness evaluation process is carried out from PR input evaluation through interim evaluation implementation and impact evaluation.

In PR input stage, following the hierarchy of objectives, the following is evaluated: a) PR implementation period stipulated on a task level and planned PR outcomes; b) on the level of target audiences features of customers (physical persons), business companies (customers and partners) and employees; c) on action plan level - suitability of planned communication means and anticipated PR outputs.

It has been stated that in a PR implementation stage it is expedient to evaluate communication messages according to the following criteria: simplicity, informativeness, veracity, ethicality, novelty, purposecenteredness of provided information, attractiveness of the media and attractiveness of communication messages' presentation.

In PR interim evaluation stage, subject to the company's decision, PR outputs and outtakes should be evaluated according to certain criteria or all of them.

In PR impact stage, it is expedient to carry out the evaluation according to the following criteria: change of target audience's knowledge and opinion, sequence of priority and relationship quality. Application of the latter in PR effectiveness evaluation process reveals implicit associations between PR and effectiveness of companies' activities.

\section{References}

Atkinson, S., \& Butcher, D. (2003). Trust in Managerial Relationships. Journal of Managerial Psychology, 18(4), 282304.

Anderson, F. W., Hadley, L., Payne, K. D., Weiner, M., \& Grunig, J. E. (1999). Guidelines for Setting Measurable Public Relations Objectives Why set Measurable PR Objectives? The Institute for Public Relations.

Bissland, J. H. (1990). Accountability Gap: Evaluation Practices Show Improvement. Public Relations Review, 16(2), 2535 .

Cutlip, S. M. (2000). Effective Public Relations. USA: Prentice Hall.

Daugherty, E. (2003). Strategic Planning in Public Relations: A Matrix That Ensures Tactical Soundness. Public Relations Quarterly, 48 (1).

Dovaliene, A., Gadeikiene, A., \& Piligrimiene Z. (2007). Customer Satisfaction and its Importance for Long-Term Relationships with Service Provider: the Case of Odontology Services. Inzinerine Ekonomika-Engineering Economics(5), 59-67.

Janonis, V., Dovaliene, A., \& Virvilaite, R. (2007). Relationship of Brand Identity and Image. Inzinerine EkonomikaEngineering Economics(1), 69-79.

Harrison, S. (2000). Public Relations. An Introduction. USA: Thomson.

Hon, Ch. L. (1998). Demonstrating Effectiveness in Public Relations: Goals, Objectives and Evaluation. Journal of Public Relations Research, 23(10), 18-26.

Hon, Ch. L. (1997). What Have You Done For Me Lately? Exploring Effectiveness in Public Relations. Journal of Rublic Relations Research, 9(1), 1-30.

Hon, Ch. L., \& Grunig, J. E. (1999). Guidelines for Measuring Relationships in Public Relations. The Institute for PR. Available at: http://www.instituteforpr.org/research_single/guidelines_measuring_relationships/.

Hon, L. Ch., \& Jung, Ki E. (2006). Relationship Maintenance Strategies on Fortune 500 Company Web Sites. Journal of Communication Management, 10(1), 27-43.

Gregory, A. (2001). Public Relations and Evaluation: Does the Reality Match the Rhetoric? Journal of Marketing Communications, 7(3), 171-189.

Kazokiene, L., \& Stravinskiene, J. (2007). Assessment of Public Relations Efficiency: Theoretical Approach. Changes in Social and Business Environment: Proceedings of the 2nd International Conference, Panevezys, Lithuania: Selected Papers, 93-97.

Kazokiene, L., \& Stravinskiene, J. (2009). Measuring the Effectiveness Public Relations Programs. International Scientific Conference Economics and Management, 14, 421-429. 
Kazokiene, L. (2010). Structure and Content of Public Relations' Objectives: Context of Business Companies. Socialiniai tyrimai. Juornal Social Research 4(21).

Kitchen, P. J. (1997). Public Relations: principles and Practice. Publisher: Int. Thomson Business Press.

Ledingham, J. A., Bruning, S. D., \& Wilson, L. J. (1999). Time as an Indicator of the Perceptions and Behavior of Members of a Key Public: Monitoring and Predicting Organization-Public Relationships. Journal of Public Relations Research, 11(2), 167-183.

Ledingham, J. A., \& Bruning, D. (2000). Public Relations as Relationship Management - A Relational Approach to the Study and Practice of Public Relations, part: A Longitudinal Study of Organization -Public Relationship: Defining the Role of Communication in the Practice of Relationship Management. Lawrence Erlbaum Associates.

Lindenmann, W. (1993). An Effectiveness Yardstick to Measure Public Relations Success. Public Relations Quarterly, 38 (1), 7-9.

Lindenmann, W. (2003). Guidelines for Measuring the Effectiveness of PR Programs and Activities. The Institute for PR. Available at: http://www.instituteforpr.org/files/uploads/2002_MeasuringPrograms_1.pdf.

Macnamara, J. (2000). Adding up the Value of PR. Total Communication Measurement, 2(10), 1-6.

Macnamara, J. (1999). Research in Public Relations: A Review of the use of Evaluation and Formative Research. Asia Pacific Public Relations Journal, 1(2), 99-103.

Nacickas, V., \& Malakauskaite, A. (2007). Efficiency of Event Usage for the Increase in Competitiveness of Companies. Inzinerine Ekonomika-Engineering Economics(2), 91-97.

Noble, P. (1999). Towards an Inclusive Evaluation Methodology. Corporate Communications: An International Journal, 4 (1), 14-23.

Patrick, F. L. (2004). Trusting the Communicators. Profile, July/August, 17.

Philips, D. (2001). The Public Relations Evaluationists. Corporate Communications: An International Journal, 6(4), 225238.

Phillips, D. (2006). Towards Relationship Management- Public Relations at the Core of Organizational Development. Journal of Communication Management, 10(2), 211-226.

Rawlins, B. L. (2008). Measuring the Relationship Between Organizational Transparency and Employee Trust. Public Relations Journal, 2 (2), 1-21.

Ross, R. D. (1972). New Dimensions for PR with Management by Objectives. Advanced Management Journal, 37(3).

Seitel, F. P. (2001). Practice of Public Relations, 8th Edition, Publisher: Prentice Hall.

Sirtautas, V., \& Sirtautiene, D. (2009). Customers Attitudes Towards Tv Commercials and the Tendencies of Their Behaviour in the Lithuanian Market: A Generational Study. Transformations in Business \& Economics, 8(3), 249264.

Smith, R. D. (2005). Strategic Planning for Public Relations. Second edt. Lawrence Erlbaum associates.

Susniene, D., \& Vanagas, P. (2006). Development of Stakeholder Relationships by Integrating Their Needs into Organization's Goals and Objectives. Inzinerine Ekonomika-Engineering Economics(3), 83-87.

Svendsen, A. (1998). The Stakeholder Strategy: Profiting From Collaborative Business Relationships. Berrett-Koehler Publishers.

Swinehart, J. (1979). Evaluating Public Relations. Public Relations Journal, 35(1), 13-16.

Urboniene, A., (2007). Expression of Organisational Commitment Among the Academic Staff. Transformations in Business \& Economics, 6(2), 133-143.

Valackiene, A. (2010). The Expression of Effective Crisis Communication in Today's Corporation: Theoretical Insights and Practical Application. Transformations in Business \& Economics, 9(1), 490-504.

Vaitkevicius, S. (2010). Comparative statistical analysis of open ended and close ended answers. 9-ojo metodologijos kongreso medziaga.

Zailskaite, L., \& Stravinskiene, J. (2008). Public Relations in Higher Education Institutions: Development of Conception and its Peculiarities. Management of Organizations: Systematic Research, 47, 141-157.

Watson, T., \& Noble, P. (2007). Evaluating Public Relations: a best Practice Guide to Public Relations Planning, Research and Evaluation. London, Philadelphia: Kogan Page.

Welch, M. (2006). Rethinking Relationship Management Exploring the Dimension of Trust. Journal of Communication Management, 10(2), 138-155.

Wilcox, D. L., Cameron, G. T., Agee, W. K., \& Ault, P. H., (2003). Public Relations: Strategies and Tactics. New York: Allyn \& Bacon. 
Inzinerine Ekonomika-Engineering Economics, 2011, 22(1), 91-105

Lina Kazokienè, Jurgita Stravinskienè

\section{Ryšių su visuomene efektyvumo vertinimo kriterijai}

Santrauka

Imonès, siekdamos sukurti pozityvų savo įvaizdị, padidinti ženklo žinomumą ar sustiprinti marketingo programų veiksmingumą, aktyviai igyvendina ryšių su visuomene (toliau - RsV) programas. Jų sėkmė neatsiejama nuo RsV efektyvumo vertinimo. RsV efektyvumo vertinimas leidžia ne tik užtikrinti veiklos atskaitingumą, bet, būdamas kompleksinio pobūdžio, igalina koreguoti veiksmus skirtingose RsV programų stadijose ir sudaro galimybę atsisakyti neracionalių sprendimų. Sparčiai plètojantis RsV, buvo vykdoma teorinių ir praktinių pagrindų pertvarka bei RsV efektyvumo vertinimo priemonių, leidžiančių RsV sprendimus susieti su verslo rezultatais, paieška. Šio straipsnio mokslinė problema - vertinimo kriterijų, leidžiančių nuosekliai ir kryptingai įvertinti RsV efektyvumą bei įrodyti RsV sprendimų tikslingumą, pagrindimas.

Straipsnio tikslas - nustatyti kompleksinio RsV efektyvumo vertinimo kriterijus verslo įmonėse. Tyrimo objektas - RsV efektyvumo vertinimo kriterijai. Tyrimo metodai - mokslinès literatūros lyginamoji, loginė ir apibendrinamoji analizė, kiekybinè ir kokybinè empirinių duomenų analizė.

Pripažistant RsV efektyvumo sampratų ịvairovę, šiame straipsnyje vadovaujamasi daugialypiu požiūriu, kad RsV efektyvumas - tai RsV sprendimų vertė i̇monei, kuri išreiškiama RsV programų efektyvumu (lyginant iškeltą tikslą ir pasiektą rezultata) bei įmonės santykių su strateginėmis auditorijomis pažanga. Atsižvelgiant ị kompleksinị RsV efektyvumo vertinimo pobūdị, grindžiamą skirtingų vertinimo etapu rezultatu grandinine reakcija, straipsnyje demesys kreipiamas ị komplekso elementų ir juos apibūdinančių kriterijų nustatymą. Dominuojantys elementai yra šie: RsV tikslai, komunikacinių pranešimu kokybè, RsV produktyvumas ir pasekmès bei galutiniai RsV rezultatai.

RsV tikslai pripažistami svarbiausiu elementu, kadangi sąlygoja visos programos sėkmę. Komunikaciniu pranešimu kokybės vertinimo metodikai tebesant eksperimentinei, apsiribojama komunikaciniais pranešimais ir jų pateikimu. Tariama, kad įvardyti elementai yra komunikacinės programos koordinavimo su auditorija dalis. RsV produktyvumo vertinimo poreikis siejamas su galimybe nustatyti RsV specialistu produktyvumą ir apibūdinti RsV taktiką. RsV pasekmiu vertinimas yra pradinis RsV poveikio vertinimo etapas, siejantis RsV veiksmus ir tikslinę auditoriją. Galima teigti, kad leidžia daryti pradines išvadas apie RsV efektyvumą. Galutiniai RsV rezultatai svarbūs dèl keliu priežasčių. Viena jų - galimybè nustatyti užsibrèžto tikslo igyvendinimą, kita - nukreipti tinkama linkme naujų RsV programų kūrimą.

Remiantis RsV efektyvumo vertinimo modeliu pavyzdžiais, teigiama, kad procesą sudaro trys etapai: RsV ivesties, igyvendinimo bei poveikio vertinimo. Pirmajame etape vertinamas RsV tikslas, antrajame - komunikaciniai pranešimai ir ju pateikimas. Paskutiniajame - poveikio vertinimo etape vertinamas RsV produktyvumas, pasekmès bei galutiniai RsV rezultatai.

Siekiant patikrinti skirtingus proceso etapus sudarančių elementų vertinimo kriterijus, atliktas kokybinis ir kiekybinis tyrimai. Atsižvelgus į teorinio ir praktinio probleminio klausimo ištyrimo lygi, RsV įvesties etape tiriamo RsV tikslo vertinimo kriterijams išsiaiškinti, taikytas kokybinis tyrimas. Šiuo atveju taikytas ekspertinio vertinimo metodas struktūrizuoto interviu forma. Kiekybinis tyrimas taikytas RsV igyvendinimo ir poveikio vertinimo kriterijams pagristi. Standartizuotos metodikos taikymo galimybė paskatino rinktis anketinès apklausos duomenu rinkimo metodą. Kokybiniame tyrime dalyvavo 20 ekspertų, atrinktų mišriosios tikslinès atrankos būdu. Kiekybiniame tyrime dalyvavo netikimybiniu tikslinių grupių formavimo būdu atrinkti 99 respondentai. Kokybinio tyrimo duomenys apdoroti naudojant turinio analizę ir hermeneutinę prieigą. Kiekybinio tyrimo duomenys rinkti siekiant išsiaiškinti respondentų nuomonę ir praktiką. Gautiems duomenims apdoroti naudota faktorinè, patikimumo ir regresinė analizès. Minėtina, kad faktorizuojant patvirtintas priemonès patikimumas ir patikslintas kintamujų sujungimas i grupes. Elementai, apibūdinantys RsV igyvendinimą, sąlygiškai ịvardyti taip: komunikacinio pranešimo paprastumas, informatyvumas, tikroviškumas, moralumas, naujumas, žiniasklaidos priemonių patrauklumas, pranešimo pateikimo patrauklumas. Elementai, apibūdinantys RsV poveiki, ívardyti taip: auditorijos demesys, informuotumas, žinių, nuomonès pokytis, abipusis pasitikèjimas, pasitenkinimas, kontrolè, isipareigojimas, mainų ir kolektyviniai santykiai.

Apibūdinant kiekvieno iš elementų vertinimo kriterijus, laikomasi procesinio nuoseklumo. RsV ivvesties etape, vertinant tikslą, nustatyti kriterijai sugrupuoti pagal tikslo hierarchinius lygius. Uždavinių lygmeniu rekomenduotina įvertinti planuojamos RsV programos igyvendinimo laikotarpi ir numatomus RsV galutinius rezultatus (žinias, nuomonès pokyyị, prioritetiškumą). Patikslinant uždavinių lygmeniu RsV igyvendinimo laikotarpio vertinimo kriterijus, išsiaiškinta, kad nurodant programos igyvendinimo trukmę, vertėtų orientuotis i planuojamam rezultatui pasiekti reikalingą minimalią ir maksimalią trukmę. Tikslinių auditorijų lygmeniu empiriškai patvirtinti šie vartotojų (fiz. asm.) savybių vertinimo kriterijai: geografiniai, psichografiniai, demografiniai, santykių su įmone, komunikacinès elgsenos, reikšmingumo. Taip pat nustatyti kiek įmanoma naujesni RsV įvesties vertinimo kontekste vartotojų savybių suvokimo kūrimo būdo ir etniniai vertinimo kriterijai. Vertinant verslo įmonių vartotojų ir verslo įmonių partnerių savybes, empiriškai patvirtinti teorinèse studijose nustatyti šie verslo įmonèse taikomi vertinimo kriterijai: geografiniai, firmografiniai, reikšmingumo. Taip pat nustatyta, kad psichografiniai, supratimo formavimo būdo, santykių su i̇mone vertinimo kriterijai gali būti taikomi vertinant verslo įmonių savybes. Vertinant tikslines darbuotojų auditorijos savybes, empiriškai patvirtinti darbo pobūdžio vertinimo kriterijai ir patikslintos demografinių bei geografiniu vertinimo kriteriju taikymo galimybès. Veiksmų plano lygmeniu rekomenduotina vertinti planuojamą RsV produktyvumą, numatomos komunikacines priemones. Tikslinant veiksmų plano lygmenyje rekomenduojamus vertinimo kriterijus, pažymėtina, kad vertinant planuojamą RsV produktyvumą tikslinga atsižvelgti į komunikacinių pranešimų sklaidą, kuri, tikètina, dažniausiai vertinama praktikoje. Šis kriterijus nėra vienintelis. Ekspertinio vertinimo rezultatai moko pastebėti, kad svarbu numatyti komunikacinių pranešimų turinị ir potencialiai pasiektą auditorijos dalį. Taip pat šiuo lygmeniu tikslinga vertinti numatomų komunikavimo priemonių tinkamumą.

Interviu duomenys leido išplèsti RsV efektyvumo vertinimo proceso pažinimą, ji papildant tarpinio vertinimo etapu bei RsV igyvendinimo ir poveikio vertinimo kriterijais, kurie analizuotose mokslininkų ižvalgose nebuvo įvardyti. Minėtų etapų vertinimo kriterijai pateikiami naudojant kokybinę ir kiekybinę analizę. RsV igyvendinimo etape nustatyti šie kriterijai: komunikacinio pranešimo sudètingumo, informuotumo, tikroviškumo, moralumo bei naujumo, teikiamos informacijos kryptingumo, žiniasklaidos priemonių patrauklumo ir pranešimo pateikimo patrauklumo vertinimo kriterijai. Respondentų nuomonès ir praktikos tyrimo rezultatai RsV igyvendinimo kriterijų klausimu iš esmès sutapo. Remiantis regresinės analizės rezultatais, $\mathrm{RsV}$ igyvendinimo etape svarbiausi yra pranešimo tikroviškumo ir žiniasklaidos patrauklumo vertinimo kriterijai, kadangi jų itaka galutiniam RsV rezultatui yra didžiausia. Tarpinio vertinimo etape, priklausomai nuo įmonès apsisprendimo, rekomenduojama vertinti visus arba dali RsV produktyvumo ir pasekmių vertinimo kriterijų. Analizuojant RsV poveikio vertinimo kriterijus, pastebėta, kad nuomonès ir praktikos tyrimo rezultatai šiek tiek skiriasi. Juos vertinant pagal įmonių veiklos sritị, šie rezultatai mažiausiai sutampa paslaugu ir gamybos įmonèse, vertinant pagal įmonių dydi, mažiausiai sutampa mažose įmonėse. Tyrimo rezultatais išsiaiškinta, kad RsV poveikio etape svarbu vertinti RsV produktyvumo, pasekmių ir galutinių rezultatų kriterijus. RsV produktyvumo vertinimas gali būti kiekybinis ir kokybinis. Identifikuoti šie RsV produktyvumo vertinimo kriterijai: auditorijos dėmesys, komunikacinių pranešimu turinys, įmonès atstovo patikimumas, potencialiai pasiekta auditorija, imonès ir jos konkurentų teikiamos žinios bei i̇monès santykine dalis, palyginant su konkurentais. Vertinant RsV pasekmes, tyrimo rezultatais patvirtintas tikslinès auditorijos informuotumo vertinimo kriterijaus tikslingumas.

Galutiniai RsV rezultatai nustatyti vadovaujantis dažniausiai sutinkamais RsV siekiais. Empirinio tyrimo rezultatais pagrịsti žinių, nuomonės, santykių pokyčio vertinimo kriterijai ir pirmumo vertinimo kriterijai. Pastarujų atveju vertinama tikslinès auditorijos dalis. Vertinant tikslinės auditorijos žinių pokytị, atsižvelgiama i tikslinès auditorijos pasiektą dali bei žinių lygị. Tikslinès auditorijos nuomonès pokytis apibūdinamas naudojant pozicionuojamų vertybių turinị, nuomonès kokybę, vartotojų pasitenkinimą, nuomonès toną ir tikslinès auditorijos dalị. Santykių pokyčiui apibūdinti gali būti taikomas santykių kokybę atspindintis kriterijus.

Raktažodžiai: ryšiai su visuomene, ryšiu su visuomene efektyvumas, efektyvumo vertinimas, efektyvumo vertinimo kriterijai.

The article has been reviewed.

Received in December, 2010; accepted in February, 2011. 